\title{
Effects of temperature, salinity and feeding frequency on growth and mortality of twaite shad (Alosa fallax) larvae
}

\author{
T. Navarro ${ }^{(1)}$, C. Carrapato(2), F. Ribeiro ${ }^{(3),(4), \star}$
}

Received June 23, 2013

Revised November 23, 2013

Accepted November 24, 2013

Key-words: clupeidae, anadromous, twaite shad, stocking, rearing

\section{ABSTRACT}

Available knowledge on the ecological requirements of the twaite shad Alosa fallax larvae is limited, restricting the development of effective management and conservation measures for this anadromous clupeid in European rivers. In this study, the effects of water temperature, salinity and feeding frequency on $A$. fallax larval growth and mortality were evaluated. For a period of ten days after the onset of exogenous feeding, A. fallax larvae exhibited higher survival rates when subjected to salinities of $2.5 \mathrm{~g} \cdot \mathrm{L}^{-1}$ and $5 \mathrm{~g} \cdot \mathrm{L}^{-1}$, from trials conducted at $0 \mathrm{~g} \cdot \mathrm{L}^{-1}, 2.5 \mathrm{~g} \cdot \mathrm{L}^{-1}$, $5 \mathrm{~g} \cdot \mathrm{L}^{-1}, 10 \mathrm{~g} \cdot \mathrm{L}^{-1}, 15 \mathrm{~g} \cdot \mathrm{L}^{-1}, 20 \mathrm{~g} \cdot \mathrm{L}^{-1}$. Higher food availability resulted in higher larval growth and survival rates during this period. Water temperature effects on larvae growth and survival was evaluated for a period of three months after hatching. Alosa fallax larvae exhibited higher growth and survival rates when subjected to temperatures of $24^{\circ} \mathrm{C}$ and $28^{\circ} \mathrm{C}$, in contrast to trials conducted at $20^{\circ} \mathrm{C}$. These results are compared to other Alosa spp. and considerations on conservation measures are discussed in light of the results.

\section{RÉSUMÉ}

Effets de la température, la salinité et la fréquence d'alimentation sur la croissance et la mortalité des larves d'alose feinte (Alosa fallax)

Mots-clés : Les connaissances disponibles sur les exigences écologiques des larves d'alose clupeidae, anadrome, conservation, feinte Alosa fallax sont faibles, limitant le développement des mesures de conservation et de gestion efficace pour ce clupéidé anadrome des rivières européennes. Dans cette étude, les effets de la température de l'eau, de la salinité et de la fréempoissonnement, quence d'alimentation sur la croissance et la mortalité des larves d'A. fallax ont été élevage évalués. Pendant une période de dix jours après le début de l'alimentation exogène, les larves d'A. fallax ont montré des taux de survie plus élevés lorsqu'elles sont soumises à des salinités de $2,5 \mathrm{~g} \cdot \mathrm{L}^{-1}$ et $5 \mathrm{~g} \cdot \mathrm{L}^{-1}$, à partir d'essais menés à $0 \mathrm{~g} \cdot \mathrm{L}^{-1}, 2,5 \mathrm{~g} \cdot \mathrm{L}^{-1}, 5 \mathrm{~g} \cdot \mathrm{L}^{-1}, 10 \mathrm{~g} \cdot \mathrm{L}^{-1}, 15 \mathrm{~g} \cdot \mathrm{L}^{-1}, 20 \mathrm{~g} \cdot \mathrm{L}^{-1}$. Une plus grande disponibilité des aliments a entraîné une croissance des larves et des taux de survie plus

(1) Faculdade de Ciências da Universidade de Lisboa, Departamento de Biologia Animal, 1749-016 Lisboa, Portugal

(2) Instituto da Conservação da Natureza e das Florestas, Parque Natural do Vale do Guadiana, Rua D. Sancho II No 15, 7750-350 Mértola, Portugal

(3) Centro de Oceanografia, Faculdade de Ciências da Universidade de Lisboa, Campo Grande 1749-016 Lisboa, Portugal

(4) Universidade de Lisboa, Museu Nacional de História Natural e da Ciência, Rua da Escola Politécnica 58, 1269-102 Lisboa, Portugal

^ Corresponding author: fmvribeiro@gmail.com 
élevés au cours de cette période. Les effets de la température de l'eau sur la croissance des larves et la survie ont été évalués pour une période de trois mois après l'éclosion. Les larves d'Alosa fallax montrent une croissance plus élevée et des taux de survie meilleurs lorsqu'elles sont soumises à des températures de $24{ }^{\circ} \mathrm{C}$ et $28^{\circ} \mathrm{C}$, contrairement aux essais réalisés à $20^{\circ} \mathrm{C}$. Ces résultats sont comparés à ceux d'autres Alosa spp. et les considérations sur les mesures de conservation sont discutées à la lumière des résultats.

\section{INTRODUCTION}

The twaite shad Alosa fallax (Lacépède, 1803) is an anadromous clupeid widespread along the Northeastern Atlantic coast, from Morocco to the Baltic Sea, and throughout the Mediterranean Sea (Quignard and Douchement, 1991). This species is in decline in most European streams (Aprahamian et al., 2003), eventhough some twaite shad populations have recovered in several estuaries (Lopéz et al., 2007; Magath and Thiel, 2013). Despite recent twaite shad populations increases human impacts remain unsolved, such as limited stream connectivity, narrowing of spawning grounds and general modification of river hydrology (Collares-Pereira et al., 2000). The combined effect of these impacts imposes significant pressures on the freshwater phases of anadromous fish life cycles, ultimately compromising recruitment (McDowall, 1992; McDowall, 1999). In addition, deterioration of water quality and overexploitation may further worsen the condition of weakened stocks (Maes et al., 2008).

Given the current population trends of anadromous fish throughout the northern hemisphere (Limburg and Waldman, 2009), the necessity for, and implementation of mitigation measures directed towards the conservation of $A$ losa species are becoming increasingly common (Waldman and Limburg, 2003; Greene et al., 2009). As so, understanding the environmental factors that mediate larval fitness is of prime importance to identify and modulate the ecological constraints underlying anadromous species decline (Jonsson et al., 1999). An increasing need to optimize larvae rearing also arises from the improvement of fish condition required to maximize effective recruitment when stocking programs are implemented (Fushimi, 2010; Brown and Day, 2002; Hendricks, 2003). Despite extensive literature on the effects of the environmental factors conditioning Alosa spp. larval development (Esteves, 2011) little information is specifically available for $A$. fallax (Esteves and Andrade, 2012). Water temperature, salinity and prey availability were recognized as important factors for twaite shad larvae abundance (Esteves, 2011), however no effects on larvae growth and mortality were studied.

The current study aimed to evaluate the effects of water temperature, salinity and feeding frequency on Alosa fallax larval growth and mortality under controlled conditions. Firstly, it was evaluated the influence of salinity and feeding frequency on larval growth and mortality after first feeding. Secondly, it was compared growth and mortality rates under different temperature treatments. The findings presented here, provide baseline information required to develop adequate measures for the successful management and conservation, such as captive rearing of twaite shad larvae and juveniles.

\section{MATERIALS AND METHODS}

Two sets of experiments were performed. The first experiment evaluated the combined effects of salinity and feeding frequency on larval growth and mortality for a short period after the onset of exogenous feeding. The second experiment assessed the effects of water temperature on growth and mortality from the embryo to the juvenile stage.

Twaite shad eggs were obtained from five females, fertilized by a dry method with sperm collected from five males, all captured while spawning in early June 2011 in the Guadiana river, Portugal (Lat: $37^{\circ} 40^{\prime} 52.45^{\prime \prime} \mathrm{N}$, Long: $7^{\circ} 39^{\prime} 43.25^{\prime \prime} \mathrm{W}$ ). An hour after collection, the eggs 
were placed in cylindrical-conical incubators under laboratorial conditions, exposed to the natural diel photoperiod. Fertilization rate was estimated $24 \mathrm{~h}$ after collection from a sample of approximately 7000 eggs.

For the first experiment, a batch of eggs was maintained in a cylindrical-conical incubator until hatching. Larvae were then transferred to a general rearing aquarium kept at a temperature of $22{ }^{\circ} \mathrm{C}\left( \pm 1^{\circ} \mathrm{C}\right)$ and salinity of $0 \mathrm{~g} \cdot \mathrm{L}^{-1}$. From this aquarium, ten larvae were distributed to each of the experimental aquaria $(n=36,1 \mathrm{~L})$ upon the onset of exogenous feeding (3rd day after hatching). Testing of salinity $\left(0 \mathrm{~g} \cdot \mathrm{L}^{-1}, 2.5 \mathrm{~g} \cdot \mathrm{L}^{-1}, 5 \mathrm{~g} \cdot \mathrm{L}^{-1}, 10 \mathrm{~g} \cdot \mathrm{L}^{-1}, 15 \mathrm{~g} \cdot \mathrm{L}^{-1}, 20 \mathrm{~g} \cdot \mathrm{L}^{-1}\right)$ and feeding frequency (once a day, $1 \times$ day $^{-1}$, and three times a day, $3 \times$ day $^{-1}$ ) was performed with three replicates per combined treatment. Desired salinities were obtained by dissolution of sea salt, larvae were fed ad libitum with freshly-hatched Artemia fransciscana nauplii and water temperature was controlled at $24^{\circ} \mathrm{C}\left( \pm 1^{\circ} \mathrm{C}\right)$. Larvae were maintained under these conditions from the onset of exogenous feeding until the 10th day after the start of the experiment. Mortality was registered daily for each replicate and total length $\left(L_{T} \pm 0.1 \mathrm{~mm}\right)$ of the surviving larvae was measured on the 10th day. Measurements took place under a microscope with an incorporated micrometric scale.

In the second experiment, approximately 1000 eggs were transferred to an incubator jar installed inside each rearing aquarium $(n=12,100 \mathrm{~L})$. This process took up to six hours past egg fertilization. Water temperature in the aquaria was controlled at $20{ }^{\circ} \mathrm{C}, 24^{\circ} \mathrm{C}$ and $28{ }^{\circ} \mathrm{C}$ $\left( \pm 1^{\circ} \mathrm{C}\right)$ in groups of four replicates per temperature treatment. After hatching, salinity was gradually raised from $0 \mathrm{~g} \cdot \mathrm{L}^{-1}$ to $4 \mathrm{~g} \cdot \mathrm{L}^{-1}\left(1 \mathrm{~g} \cdot \mathrm{L}^{-1} \cdot \mathrm{day}^{-1}\right)$ for all replicates. Larvae were initially fed three times a day (morning, noon, evening) with approximately $10^{6}$ freshly-hatched Artemia franciscana nauplii per aquarium. Weaning began at the 45th day after hatching with $0.5 \mathrm{~mm}$ pellets (Skretting Gemma Wean Diamond) and was extended until the 75th day. From the 75th day onwards larvae were fed solely on this formulated diet, six times a day. During the first month post hatching (Period I), 20 larvae were measured $\left(L_{T} \pm 0.1 \mathrm{~mm}\right)$ from each replicate every other day. For the second and third months post hatching (Period II), 20 larvae were measured per replicate every two weeks. Larvae were anesthetized prior to measuring in a $0.5 \mathrm{~mL} \cdot \mathrm{L}^{-1}$ solution of clove oil in order to reduce stress and improve measurement accuracy.

\section{> DATA ANALYSIS}

For the first experiment, $L_{T}$ attained at the 10th day after first feeding was compared using non-parametric statistics, as data did present neither a normal distribution nor homogeneity of variances, even after $\log _{10}$ transformation (Zar, 1999). In each feeding frequency treatment, a Kruskal-Wallis test was performed to compare differences between sizes $\left(L_{T}\right)$ among salinity treatments, and was followed by a Dunn test as post hoc comparison (Zar, 1999). Mann-Whitney tests were run to compare differences between sizes $\left(L_{T}\right)$ between the two feeding frequencies in each salinity treatment (Zar, 1999). Mean treatment mortality rates were calculated as the number of surviving larvae relatively to the initial number of larvae in each aquarium. Differences between mortality rates among salinity treatments for each feeding frequency were accessed through survival curves comparison using the logrank test, a modification of Gehan-Wilcoxon test. Analysis was performed using "survival" R-package (function = survdiff, rho $=1$ ) $($ R-project).

For the second experiment, linear regressions were determined for each temperature treatment between attained $\mathrm{L}_{\top}$ and time (days after fertilization) for each of the two growth periods (Period I - first month; Period II - second and third months), considering the replicate data together. Linear regressions within each period were compared across temperature treatments by means of an ANCOVA. Normality and homoscedasticity were tested, using Shapiro-Wilk and Levene tests respectively (Zar, 1999). Mean mortality rates were determined for each temperature treatment at the end of the experiment by determining the number of surviving larvae relatively to the estimated number of hatched larvae (number of eggs $\times$ fertilization rate). Differences between observed mortality rates were accessed using a $\chi^{2}$ test. All data and statistical analysis were performed using $R$ software (R-project). 


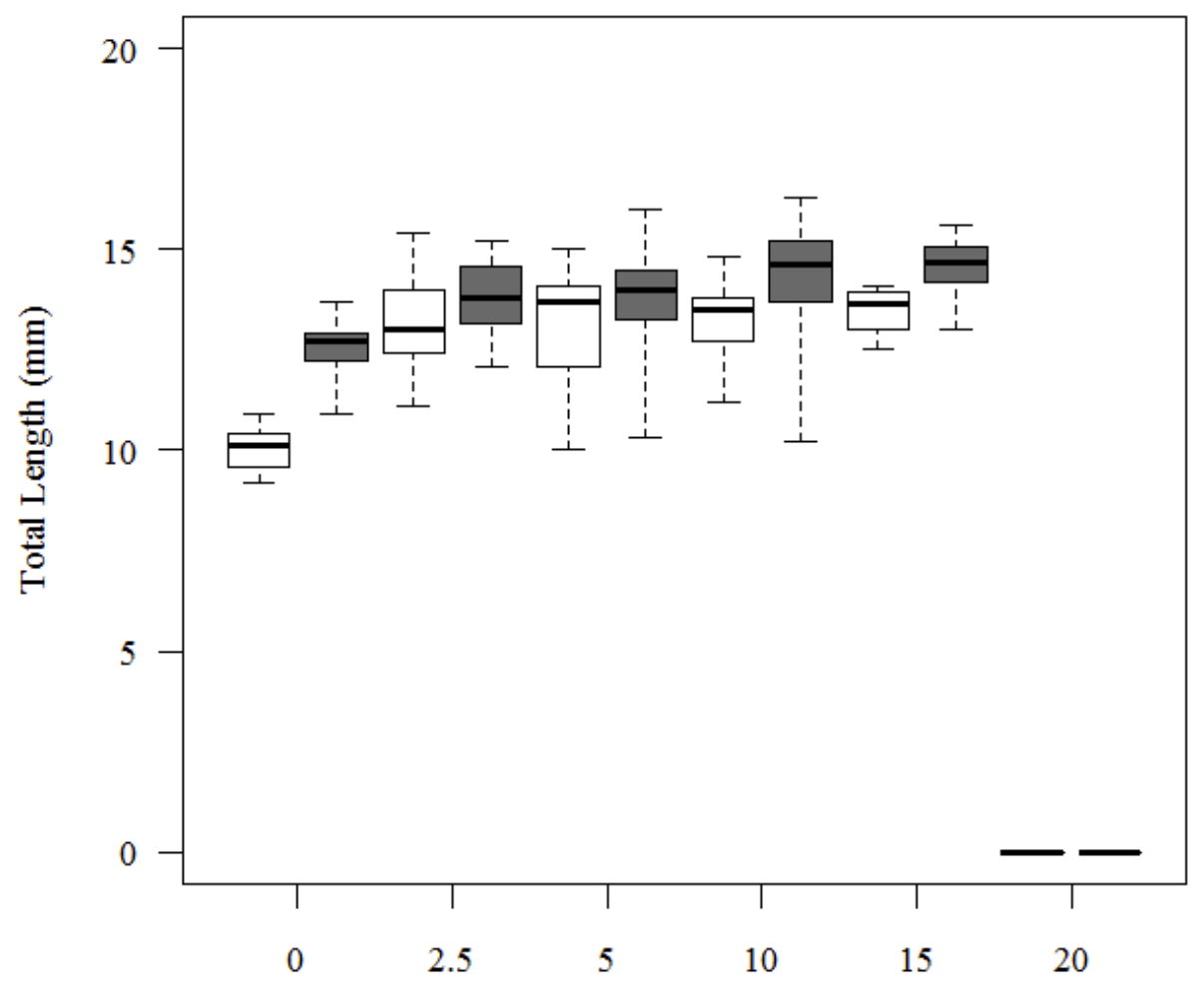

Feeding and Salinity Treatment (g.L-1)

\section{Figure 1}

Box-plots with mean total length $\left(L_{\mathrm{T}}, \mathrm{mm}\right)$ attained by Alosa fallax larvae at the 10th day after first feeding when fed once a day (white) and three times a day (grey) per salinity treatments; box represent the upper and lower quartiles and lines represent minimum and maximum values; $20 \mathrm{~g} \cdot \mathrm{L}^{-1}$ treatment not represented due to high mortality rates.

\section{RESULTS}

Larval total length varied significantly according to salinity in both feeding tests: $1 \times$ day $^{-1}$ (Kruskal-Wallis test, $\chi^{2}=40.771, P<0.001$, d.f. 4 ) and $3 \times$ day $^{-1}$ (Kruskal-Wallis test, $\chi^{2}=$ 28.909, $P<0.001$, d.f. 4) (Figure 1). Larvae fed $1 \times$ day $^{-1}$ at $0 \mathrm{~g} \cdot \mathrm{L}^{-1}$ were significantly smaller than those subjected to $2.5 \mathrm{~g} \cdot \mathrm{L}^{-1}, 5 \mathrm{~g} \cdot \mathrm{L}^{-1}, 10 \mathrm{~g} \cdot \mathrm{L}^{-1}$ (Dunn test, $Q>3.291, P<0.01$, d.f. 5 ) and $15 \mathrm{~g} \cdot \mathrm{L}^{-1}$ (Dunn test, $Q>2.807, P<0.05$, d.f. 5). Larvae fed $3 \times$ day $^{-1}$ at $0 \mathrm{~g} \cdot \mathrm{L}^{-1}$ were also significantly smaller than those kept at $2.5 \mathrm{~g} \cdot \mathrm{L}^{-1}, 10 \mathrm{~g} \cdot \mathrm{L}^{-1}, 15 \mathrm{~g} \cdot \mathrm{L}^{-1}$ (Dunn test, $Q>3.291$, $P<0.01$, d.f. 5) and $5 \mathrm{~g} \cdot \mathrm{L}^{-1}$ (Dunn test, $Q>2.807, P<0.05$, d.f. 5). Fish larvae fed less frequently presented significantly smaller mean $L_{T}$ at all salinity treatments (Mann-Whitney test, $P<0.05$ ) except for $5 \mathrm{~g} \cdot \mathrm{L}^{-1}$ (Mann-Whitney test, $U=200.5, P>0.05$ ).

Mortality was found to differ significantly among salinity treatments for both feeding frequencies $\left(1 \times\right.$ day $^{-1}, \chi^{2}=220, P<0.001$, d.f. 5 ; $3 \times$ day $^{-1}, \chi^{2}=227, P<0.001$, d.f. 5). Mean mortality rates generally increased with salinity regardless of feeding frequency, the exception being larvae kept at $0 \mathrm{~g} \cdot \mathrm{L}^{-1}$ that presented higher mortality rates $(\approx 40.0 \%)$ than those kept at $2.5 \mathrm{~g} \cdot \mathrm{L}^{-1}(\approx 10.0 \%)$ and at $5 \mathrm{~g} \cdot \mathrm{L}^{-1}(\approx 30.0 \%$, Figure 2$)$. A salinity of $20 \mathrm{~g} \cdot \mathrm{L}^{-1}$ was lethal $(100.0 \%)$ in a couple of days after exposition. Higher feeding frequency lead to lower mortality rates particularly at $15 \mathrm{~g} \cdot \mathrm{L}^{-1}$ (Figure 2 ).

The three different temperature treatments resulted in significantly different growth rates in both Period I and Period II (Table I, Figure 3). During Period I, larvae subjected to $20^{\circ} \mathrm{C}$ exhibited lowered growth rates in comparison to those exhibited by larvae subjected to $24^{\circ} \mathrm{C}$ (ANCOVA, $F=4047, P<0.001$, d.f. 1,1161 ) and $28{ }^{\circ} \mathrm{C}$ (ANCOVA, $F=4620, P<0.001$, d.f. 1,1229$)$. In Period II, this pattern was similar with larvae reared at $20^{\circ} \mathrm{C}$ exhibiting lower 

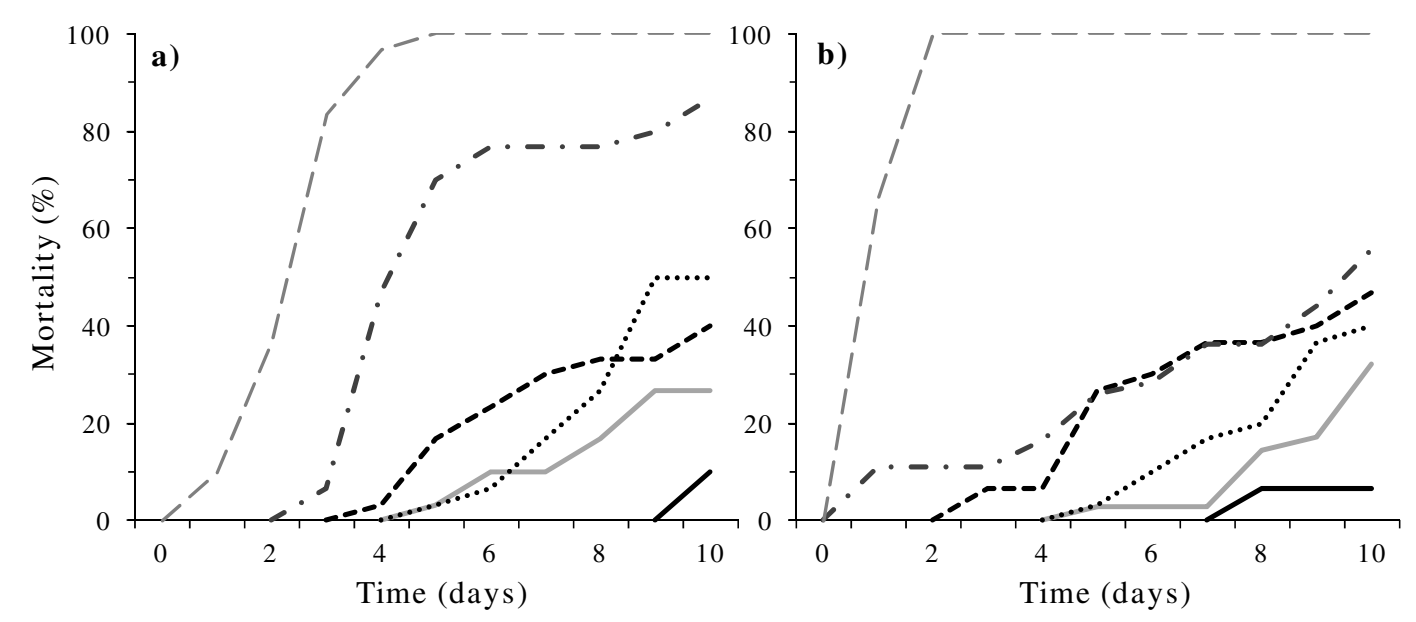

--0 g.L-1 2,5 g.L-1 $\longrightarrow$ g.L-1

10 g.L-1 $\quad-\cdots 15$ g.L-1 $\quad-\quad 20$ g.L-1

Figure 2

Mean cumulative mortality (\%) for the two different feeding frequencies treatments ( $a$ - once a day; $b-$ three times a day) per salinity treatments: $0 \mathrm{~g} \cdot \mathrm{L}^{-1}$ - black dashed line; $2.5 \mathrm{~g} \cdot \mathrm{L}^{-1}$ - black solid line; $5 \mathrm{~g} \cdot \mathrm{L}^{-1}$ grey solid line; $10 \mathrm{~g} \cdot \mathrm{L}^{-1}$ - black dotted line; $15 \mathrm{~g} \cdot \mathrm{L}^{-1}$ - black dotted-dashed line; $20 \mathrm{~g} \cdot \mathrm{L}^{-1}$ - grey dashed line.

\section{Table I}

Growth rates determined from linear relationship between Total Length $\left(L_{T}, \mathrm{~mm}\right)$ and Time $(T$, days) for the three temperature treatments in the two different periods: $L_{T}=a+b T$, where " $b$ " is the slope and " $a$ " is the intercept; $R^{2}$ is the explained variation; values of the T-test $(t)$ and associated $p$-values $(P)$.

\begin{tabular}{|l|c|c|c|c|c|c|}
\hline Period & Temperature & $a$ & $b$ & $R^{2}$ & $T$ & $P$ \\
\hline \multirow{4}{*}{ I } & $20^{\circ} \mathrm{C}$ & 7.06 & 0.20 & 0.68 & 32.02 & 0.00 \\
\cline { 2 - 7 } & $24^{\circ} \mathrm{C}$ & 6.79 & 0.39 & 0.87 & 67.19 & 0.00 \\
\cline { 2 - 7 } & $28^{\circ} \mathrm{C}$ & 6.55 & 0.40 & 0.88 & 70.60 & 0.00 \\
\hline \multirow{3}{*}{ II } & $20^{\circ} \mathrm{C}$ & 12.46 & 0.12 & 0.23 & 5.73 & 0.00 \\
\cline { 2 - 7 } & $24^{\circ} \mathrm{C}$ & 12.23 & 0.20 & 0.45 & 15.61 & 0.00 \\
\cline { 2 - 7 } & $28^{\circ} \mathrm{C}$ & 12.09 & 0.18 & 0.44 & 15.81 & 0.00 \\
\hline
\end{tabular}

growth rates than larvae reared at $24^{\circ} \mathrm{C}$ (ANCOVA, $F=279, P<0.001$, d.f. 1,415 ) and $28^{\circ} \mathrm{C}$ (ANCOVA, $F=282, P<0.001$, d.f. 1, 431). Growth rates between treatments at $24{ }^{\circ} \mathrm{C}$ and $28^{\circ} \mathrm{C}$ were significantly different for Period I (ANCOVA, $F=9475, P<0.001$, d.f. 1,1434 ) and Period II (ANCOVA, $F=492, P<0.001$, d.f. 1, 622) (Table I). There was a reduction on growth during Period II relatively to Period I (Figure 3, Table I). Mean mortality observed at the end of the experiment was significantly different among temperature treatments $\left(\chi^{2}=415.822\right.$, $P<0.001$, d.f. 2), being similar for individuals kept at $24{ }^{\circ} \mathrm{C}(71.2 \% \pm 11.0 \%)$ and $28{ }^{\circ} \mathrm{C}$ $(72.6 \% \pm 6.7 \%)$ while much higher at $20{ }^{\circ} \mathrm{C}(98.3 \% \pm 0.6 \%)$.

\section{DISCUSSION}

The results obtained with the present experimental work provide the first insight on the growth and mortality responses of larval $A$. fallax when subjected to distinct temperature, salinity and feeding frequency treatments under laboratorial conditions. Overall, these results were in accordance with available information for other North American (e.g. Leach and Houde, 1999; Jia et al., 2009) and European Alosa species (e.g. Aprahamian and Aprahamian, 2001; Bardonnet and Jatteau, 2008). Young $A$. fallax larvae were able to withstand environments with salinities ranging from $0 \mathrm{~g} \cdot \mathrm{L}^{-1}$ up to $15 \mathrm{~g} \cdot \mathrm{L}^{-1}$, thriving at $2.5 \mathrm{~g} \cdot \mathrm{L}^{-1}$ while being unable to survive at $20 \mathrm{~g} \cdot \mathrm{L}^{-1}$. Food availability improved growth and survival of $A$. fallax larvae, while lower water temperatures $\left(20^{\circ} \mathrm{C}\right)$ led to the reduction of both growth and survival. 


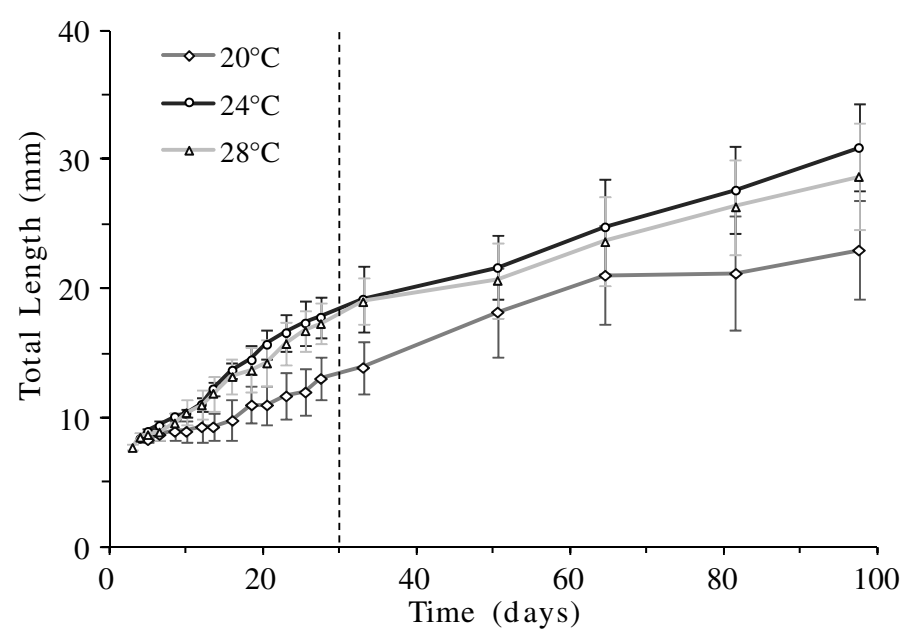

Figure 3

Mean total length $\left(\mathrm{L}_{\mathrm{T}}, \mathrm{mm}\right)$ attained by Alosa fallax larvae along the 90 days experiment for each treatment temperature $\left(20^{\circ} \mathrm{C}\right.$ - diamond, dark grey line; $24^{\circ} \mathrm{C}$ - circle, black line; $28^{\circ} \mathrm{C}$ - triangle, light grey line; bars represent standard deviations); vertical dashed line represents the beginning of Period II.

Alosa fallax mainly spawns in tidal freshwater, where both eggs and young larvae may passively drift to oligohaline and mesohaline environments (Caswell and Aprahamian, 2001; Esteves and Andrade, 2008). During the downstream drift, larvae face an increasing salinity gradient that can exert a significant environmental pressure when functional osmoregulation is not yet fully developed (Limburg and Ross, 1995; Bardonnet and Jatteau, 2008). In fact, young Alosa spp. larvae are known to be unable to osmoregulate at sea salinity (Zydlewski and McCormick, 1997; Leguen et al., 2007) and herein a salinity of $20 \mathrm{~g} \cdot \mathrm{L}^{-1}$ was lethal to young $A$. fallax larvae in a couple of days after exposition. Conversely, the lowest mortality rates for young $A$. fallax larvae were observed at oligohaline environments $\left(2.5 \mathrm{~g} \cdot \mathrm{L}^{-1}\right.$ and $5 \mathrm{~g} \cdot \mathrm{L}^{-1}$ ) supporting the hypothesis that these environments are more suitable to this species. The reduced osmotic pressure difference between the larvae and its environment might enable a higher investment in development rather than osmoregulation, increasing larvae condition and survival (Limburg and Ross, 1995). The higher Alosa spp. larvae abundances observed by Esteves and Andrade (2008) in the oligohaline and mesohaline sections of the Guadiana estuary support these results. However, $A$. fallax larvae presented clear differences in salinities optimum relatively to other Alosa spp., with $A$. alosa and $A$. sapidissima larvae optimum closer to $10 \mathrm{~g} \cdot \mathrm{L}^{-1}$ (Limburg and Ross, 1995; Bardonnet and Jatteau, 2008). The observed salinity optima differences for larvae growth and survival could result from species specific physiologic development. However, distinct methodological approaches were used between the current study and others previously mentioned. For instance, Bardonnet and Jatteau (2008) analyzed different larval stages and had a different experimental set regarding exposure time and salinity ranges.

Food availability and quality are recognized as utmost important aspects to improve fish larvae growth and survival (Houde, 2008; Fushimi, 2010). Concordantly, in the current study, increasing feeding frequency enhanced both growth and survival of $A$. fallax larvae. The observed differences in mortality between feeding treatments were greater at a higher salinity $\left(15 \mathrm{~g} \cdot \mathrm{L}^{-1}\right)$. When subjected to this condition, a higher feeding frequency greatly improved young $A$. fallax larvae survival, providing indirect evidence of the high energetic requirements of osmoregulation, and the dependence of fish on a sure exogenous energy intake during early life (Wiggins et al., 1985; Johnson and Dropkin, 1995). Due to Artemia spp. nauplii limited survivability in freshwater (Lavens and Sorgeloos, 1996), at $0 \mathrm{~g} \cdot \mathrm{L}^{-1}$ larval growth was hampered by low prey availability (live nauplii) when in comparison to higher salinity treatments.

Alosa spp. larvae fish growth is intrinsically dependent on temperature as it is a determining factor of poikilothermic metabolic rates (Aprahamian and Aprahamian, 2001). In fact, twaite 
shad larvae growth rates seemed to increase with increasing water temperature (Figure 3), however some of the observed growth rate differences $\left(24{ }^{\circ} \mathrm{C}\right.$ and $\left.28{ }^{\circ} \mathrm{C}\right)$ are not biologically meaningfull. The results seem to suggest that $A$. fallax larvae have a thermal optimum $\left(\approx 24^{\circ} \mathrm{C}\right)$ above the most commonly experienced temperatures during the spawning season in the Guadiana and other rivers (Gerkens and Thiel, 2001; Esteves and Andrade, 2008). As the spawning season progresses (from March to June) later larvae cohorts may benefit from increasing water temperature. From RNA/DNA ratios, Esteves et al. (2009) found that metabolic activity is potentiated by the higher temperatures to which $A$. fallax larvae are exposed later in the spawning season, which also potentiate general ecosystem productivity providing larvae with a higher abundance of resources (Crecco and Savoy, 1985). In contrast, Esteves and Andrade (2012) observed that the highest growth rates for $A$. fallax larvae occurred early in the spawning season, suggesting that maybe only the fastest growing larvae survive during this period. According to Perez and Munch (2010), faster growing larvae tend to present higher individual fitness given that developed fish are able to swim, feed and avoid predation more efficiently. These aspects should be further investigated in the light of the results here presented for the population of the Guadiana river. Considering that this river shelters the southernmost Atlantic populations of the European Alosa spp. (Quignard and Douchement, 1991), it would be of particularly interest to assess possible thermal optima shifts relatively to Northern Atlantic populations (Houde, 1989; Arendt, 1997).

The effects of salinity, temperature and feeding on $A$. fallax larvae growth and mortality are unlikely to be shaped by major methodological shortcomings. Despite the high mortality registered during larval development relatively to other ex situ studies (e.g. Howey, 1985), clearly different responses to the tested factors were observed among treatments. Some methodological limitations such as timing of weaning and food type probably led to increased mortality, but these effects were constant among treatments. Smaller pellet sizes and delayed weaning should be considered in future research studies aiming for higher larvae survivability. Additionally, comparing lengths between deceased and live fish should provide an insight on the hypothesis that faster growth would result in increased survivability (Houde, 2002). In the current study, only young larvae tested for their responses to different salinity and food availability treatments and future studies should be extended to comprise older larval stages (e.g. Leguen et al., 2007). Nonetheless, the effects of these two factors are likely to most strongly influence larvae growth and mortality at an early age, when the osmotic and digestive systems are still developing (Lavens and Sorgeloos, 1996; Zydlewski and McCormick, 1997).

The early life stages are considered as the most critical in fish development, when environmental conditions have greater influence on larval growth and survival (Blaxter, 1974; Houde, 1987). Anadromous Alosa spp. larvae and juvenile stages are bound to occur in upper estuaries, in tidal freshwater and brackish waters (Esteves, 2011). However, these environments are subjected to high anthropogenic intervention and, in the Guadiana catchment, the increasing water demand for human consumption has been exacerbating the impacts on the estuarine system (Collares-Pereira et al., 2000; Costa et al., 2001). The recent human derived changes have altered water thermal and haline regimens and consequently the estuary production and food availability patterns as a result of river flow regulation (Morais et al., 2009). These changes in water parameters could have significant effects on anadromous species effective recruitment as suggested by Esteves et al. (2009) and supported by current results. To improve the condition of nursery habitats, ecological flows should be implemented in order to achieve a balance between leading environmental factors, such as temperature and salinity, and enhance $A$. fallax recruitment (Chícharo et al., 2006). These ecological flows should enhance twaite shad recruitment, by increasing water temperature $\left(\approx 24{ }^{\circ} \mathrm{C}\right)$ and extending mesohaline section of the estuary $\left(\approx 5-18 \mathrm{~g} \cdot \mathrm{L}^{-1}\right)$, and consequently increasing larvae growth rates and reduce fish mortality. The results here presented come as a much needed complement to the ecological knowledge on this species, providing also some baseline information that might be useful for future rearing programs as potential measures for the conservation of this threatened anadromous species (Philippart, 1995; Sarrazin and Barbault, 1996). 


\section{ACKNOWLEDGEMENTS}

This study was conducted under permit from the Institute for Nature Conservation and Biodiversity (License Nr.10070/2011/UACI, June 8th). The Portuguese Science Foundation supported F. Ribeiro (SFRH/BPD/46761/2008). Thanks are due to the team stationed at the Guadiana Valley's Natural Park for assistance with the experiments and to J. Confeiteiro for field expertise and support provided during specimen collection. The authors are thankful to Z. Reveley for English revision of an early draft of the manuscript.

\section{REFERENCES}

Aprahamian M.W. and Aprahamian C.D., 2001. The influence of water temperature and flow on year class strength of twaite shad (Alosa fallax fallax) from the river Severn, England. Bull. Fr. Pêche Piscic., 362/363, 953-972.

Aprahamian M.W., Baglinière J.L., Sabatié M.R., Alexandrino P., Thiel R. and Aprahamian C.D., 2003. Biology, status, and conservation of the anadromous Atlantic twaite shad Alosa fallax fallax. Am. Fish. Soc. Symp., 35, 103-124.

Arendt J.D., 1997. Adaptive intrinsic growth rates: an integration across taxa. Q. Rev. Biol., 72, 149-177.

Bardonnet A. and Jatteau Ph., 2008. Salinity tolerance in young Allis shad larvae (Alosa alosa L.). Ecol. Freshw. Fish, 17, 193-197.

Blaxter J.H.S., 1974. The early life history of fish, Springer Verlag, Berlin, $756 \mathrm{p}$.

Brown C. and Day R.L. 2002 The future of stock enhancements: lessons for hatchery practice from conservation biology. Fish. Fish., 3, 79-94.

Caswell P. and Aprahamian M.W., 2001. Use of river habitat survey to determine the spawning habitat characteristics of twaite shad (Alosa fallax fallax). Bull. Fr. Pêche Piscic., 362/363, 919-929.

Chícharo L., Chícharo M.A. and Ben-Hamadou R., 2006. Use of a hydrotechnical infrastructure (Alqueva Dam) to regulate planktonic assemblages in the Guadiana estuary: basis for the sustainable water and ecosystem services management. Estuar. Coastal Shelf Sci., 70, 3-18.

Collares-Pereira M.J., Cowx I.G., Ribeiro F., Rodrigues J.A. and Rogado L., 2000. Threats imposed by water development schemes on the conservation of endangered fish species in the Guadiana River Basin in Portugal. Fish. Manag. Ecol., 7, 167-178.

Costa M.J., Almeida P.R., Domingos I.M., Costa J.L., Correia M.J., Chaves M.L. and Teixeira C.M., 2001. Present status of the main shads' populations in Portugal. Bull. Fr. Pêche Piscic., 362/363, 1109-1116.

Crecco V.A. and Savoy T.F. 1985 Effects of biotic and abiotic factors on growth and relative survival of young American shad, Alosa sapidissima, in the Connecticut river. Can. J. Fish. Aquat. Sci., 42, 1640-1648.

Esteves E., 2011. Ecology of early life-history stages of anadromous shads. Ecology In: Dempsey S.P. (ed.), Fish ecology, Nova Science Publishers Inc. New York, 151-172.

Esteves E. and Andrade J.P., 2008. Diel and seasonal distribution patterns of eggs, embryos and larvae of Twaite shad Alosa fallax fallax (Lacépède, 1803) in a lowland tidal river. Acta Oecol., 34, 172-185.

Esteves E. and Andrade J.P., 2012. Intrannual effects of biotic and abiotic factors on growth and mortality of anadromous twaite shad, Alosa fallax fallax (Lacépède, 1803), larvae. In: Pourali K. and Raad V.N. (eds.) Larvae: morphology, biology, and life cycle, Nova Science Publishers Inc. New York, 57-82.

Esteves E., Pina T. and Andrade J.P., 2009. Diel and seasonal changes in nutritional condition of the anadromous twaite shad Alosa fallax fallax (Lacépède, 1803) larvae. Ecol. Freshw. Fish, 18, $132-144$.

Fushimi H., 2010. Production of juvenile marine fish for stock enhancement in Japan. Aquaculture, 200, 33-53.

Gerkens M. and Thiel R., 2001. Habitat use of age - 0 twaite shad (Alosa fallax Lacépède, 1803) in the tidal freshwater region of the Elbe river, Germany. Bull. Fr. Pêche Piscic., 362/363, 773-784.

Greene K.E., Zimmerman J.L., Laney R.W. and Thomas-Blate J.C., 2009. Atlantic coast diadromous fish habitat: A review of utilization, threats, recommendations for conservation, and research needs. ASMFC Habitat Management Series No. 9, Washington, D.C, 464 p.

Hendricks M.L., 2003. Culture and transplant of alosines in North America. In: Limburg K.E. and Waldman J.R. (eds.), Biodiversity, status, and conservation of the world's shads, American Fisheries Society, 35, Bethesda, Maryland, 303-312. 
Houde E.D., 1987. Fish early life dynamics and recruitment variability. Am. Fish. Soc. Symp., 2, 17-29.

Houde E.D., 1989. Comparative Growth, Mortality, and Energetics of Marine Fish Larvae: Temperature and Implied Latitudinal Effects. Fish. Bull., 87, 471-495.

Houde E.D., 2002. Mortality. In: Fuiman L.A. and Werner R.G. (eds.), Fisheries science - the unique contributions of early life stages, Blackwell Science Ltd, Oxford, 64-87.

Houde E.D., 2008. Emerging from Hjort's Shadow. J. Northwest Atl. Fish. Sci., 41, 53-70.

Howey R.G., 1985. Intensive culture of juvenile american shad. Prog. Fish-Cult., 47, 203-212.

Jia Y., Liu Q., Goudie C.A. and Simco B.A., 2009. Survival, growth, and feed utilization of pre- and postmetamorphic american shad exposed to increasing salinity. N. Am. J. Aquac., 71, 197-205.

Johnson J.H. and Dropkin D.S., 1995. Effects of prey density and short term food deprivation on the growth and survival of American shad larvae. J. Fish Biol., 46, 872-879.

Jonsson B., Waples R.S. and Friedland K.D., 1999. Extinction considerations for diadromous fishes. J. Mar. Sci., 56, 405-409.

Lavens P. and Sorgeloos P., 1996. Manual on the production and use of live food for aquaculture, FAO Fish. Tech. Pap., 361, 295 p.

Leach S.D. and Houde E.D., 1999. Effects of environmental factors on survival, growth, and production of american shad larvae. J. Fish Biol., 54, 767-786.

Leguen I., Véron V., Sevellec C., Azam D., Sabatié R., Prunet P. and Baglinière J.L., 2007. Development of hypoosmoregulatory ability in allis shad Alosa alosa. J. Fish Biol., 70, 630-637.

Limburg K.E. and Ross R.M., 1995. Growth and mortality rates of larval american shad, Alosa sapidissima, at different salinities. Estuaries, 2, 335-340.

Limburg K.E. and Waldman J.R., 2009. Dramatic declines in North Atlantic diadromous fishes. BioScience, 59, 955-965.

Lopéz M.A., Gázquez N., Olmo-Vidal J.M., Aprahamian M.W. and Gisbert E. 2007. The presence of anadromous twaite shad (Alosa fallax) in the Ebro River (western Mediterranean, Spain): an indicator of the population's recovery? J. Appl. Ichthyol., 23, 163-166.

Maes J., Stevens M. and Breine J., 2008. Poor water quality constrains the distribution and movements of twaite shad Alosa fallax fallax (Lacépède, 1803) in the watershed of River Scheldt. Hydrobiologia, $602,129-143$.

Magath V. and Thiel R., 2013. Stock recovery, spawning period and spawning area expansion of the twaite shad Alosa fallax in the Elbe estuary, southern North Sea. Endanger. Species Res., 20, 109-119.

McDowall R.M., 1992. Particular problems for the conservation of diadromous fish. Aquat. Conserv. Mar. Freshw. Ecosys., 2, 351-355.

McDowall R.M., 1999. Different kinds of diadromy: Different kinds of conservation Problems. J. Mar. Sci., 56, 410-413.

Morais P., Chícharo M.A. and Chícharo L., 2009. Changes in a temperate estuary during the filling of the biggest European dam. Sci. Total Environ., 407, 2245-2259.

Perez K.O. and Munch S.B., 2010. Extreme selection on size in the early lives of fish. Evolution, 64, 2450-2457.

Philippart J.C., 1995. Is captive breeding an effective solution for the preservation of endemic species? Biol. Cons., 72, 281-295.

Quignard J.P. and Douchement C., 1991. Alosa fallax fallax (Lacépède, 1803). In: Hoestlandt H. (ed.), The Freshwater Fishes of Europe, Clupeidae, Anguillidae, Vol. 2, Aula-Verlag Wiesbaden, 225-256.

Sarrazin F. and Barbault R., 1996. Reintroduction: challenges and lessons for basic ecology. Trends Ecol. Evol., 11, 474-478.

Waldman J.R. and Limburg K.E., 2003. The world's shads: Summary of their status, conservation, and research needs. In: Limburg K.E. and Waldman J.R. (eds.), Biodiversity, status, and conservation of the world's shads, American Fisheries Society Symposium 35, Bethesda, Maryland, 363-369.

Wiggins T.A., Bender T.R.Jr., Mudraka V.A. and Coll J.A., 1985. The development, feeding, growth, and survival of cultured American shad larvae through the transition from endogenous to exogenous nutrition. Progr. Fish-Cult., 47, 87-93.

Zar J.H., 1999. Biostatistical Analysis, 4th ed. Prentice Hall, Upper Saddle River, NJ, 662 p.

Zydlewski J. and McCormick S.D., 1997. The ontogeny of salinity tolerance in the American shad, Alosa sapidissima. Can. J. Fish. Aquat. Sci., 54, 182-189. 